\title{
Brutalism: The Socio-Political and Technological Effect on Postcolonial Modern Architecture in Indonesia
}

\author{
Nia Namirah $\operatorname{Han}^{1 *}$ and Kemas Ridwan Kurniawan ${ }^{1}$ \\ ${ }^{1}$ Facutly of Engineering, University of Indonesia, Depok City 16424, Indonesia
}

\begin{abstract}
Brutalism, as a style in modern architecture, escaped from the architectural critic's attention in Indonesia. This is due to the lack of building architecture influenced by this style, as well as the difficulty of distinguishing this style from monumentalism in architecture in Indonesia. Its existence cannot be separated from the development of the Architectural industry in Indonesia. The cement factory - which is the main raw material of concrete - has an impact on infrastructure growth in Indonesia. The establishment of the first cement factory in the Netherlands Indies (Indonesia) as well as in Southeast Asia named NV Nederlandsch Indisch Portland Cement Maatschaapij (NV NIPCM) in 1910 is one of the starting point of industrial development and architectural technology in the country. During the Old Order period, cement was the main raw material for infrastructure development. In line with the vision of the first President of the Republic of Indonesia, Ir. Soekarno, to build the character of a modern nation in the era of Guided Democracy (1957-1965), it must also be represented through the works of sturdy and durable monumental architecture. Meanwhile, during the New Order period, the development of Indonesian architecture was strongly influenced by the political condition and national stability, followed by the inclination to create Indonesian architectural identity with traditional concept. This paper attempts to discuss the link between modern architecture in Indonesia and Brutalism, in relation to the sociopolitical and technological aspects of the Old Order and the New Order. A Qualitative method that based on historical criticism was used to answer the question.
\end{abstract}

\section{Introduction}

Derrida once said at his interview with Eva Meyer, about the 'Desire' and 'Spatialisation' [8]. The two is driver of the presence of architecture, that the architecture must be a place that reads the user's desires. Tschumi through 'the Pleasure of Space' [5] said that architecture only occurs when desire is reflected and is moved naturally under the conscious. While Michael Hays [11], architecture is when it is intervention and sense of art. Tjahjono [7] said, there are five factors of the presence of architecture, and they are: 1)

\footnotetext{
* Corresponding author: nianamirahanum@gmail.com
} 
Desire to sustain life; 2) Desire to live with; 3) Live peacefully; 4) Desire for selfstatement; 5) Inherit self-image.

From Ardhiati [15] the four philosphies about the driving factors of the presence of architectutre, it can be drawn into a trilogy: Desire, Intervention, and Sense of Art. The desire can be anything, one of them in architecture is the desire to live well to maintain the existence by presenting architecture. But it is impossible that desire will be realized if there is no intervention from the ruler or leader, so that the process of creating architecture can run according to and the meaning to be conveyed. The sense of art, is intended as a manifestation of human aesthetic taste formed from elements in the form of lines, colors, light, which are composed in composition accompanied by proportions, patterns, and rhythms. And this sense of art which acts a trigger in the form, proportion, pattern and impression that is embedded in the building of Brutalism.

Brutalism is a new architectural movement that had emerged in the 1950s [9] especially in Britain, and in other European countries, which enforce functional principles in materials and structures. As the name implies, which is taken from the French 'béton brut' (raw concrete), this style of Brutalism architecture displays the aesthetics of concrete material and has a form of boxes, hard, rough (without finishing) and unrefined by avoiding the use of 'cosmetic' (ornament) inside it. Because of its very basic concept, Brutalism architecture become a public target in European countries to rebuild after World War II with a minimal budget to create a new infrastructure that could sustain the people's welfare at that time. In Britain, this Brutalism Architecture was initiated by Alison and Peter Smithson.

In Indonesia, the massive post-colonial urban infrastructure development took place in the era of guided democracy (1959-1966) proclaimed by President Soekarno in his strategy of confronting the political crisis and the 1950s uprising, until the issuance of the Presidential Decree of July 5th 1959, to restore all power to the President [1]. At that time, Soekarno began to build the vision of a modern Indonesian nation, with a form of architectural discourse that he assured can highlight Indonesia to the world. Soekarno initiated and involved in the process of building monuments and important buildings that are dominant with the use of concrete in Jakarta. Soekarno has a great desire to build a solid and timeless monumental building. Like his speech on the construction of the First National Mosque column (Istiqlal Mosque) :

\section{“...Which made of concrete, which resistant from earthquake and from the erosion of the time." [13]}

Thus, began a massive development in Jakarta, especially with the 4th ASEAN Games that was held in Jakarta in 1962 and the meeting of countries that are members of the New Emerging Forces (CONEFO) initiated by Soekarno. During the New Order period, development was emphasized on achieving national stability and economic stability, through national development that departed from the national cultural roots [1]. In practice, however, the New Order allows capitalism as a tool of development by opening the gates as widely as possible for private and foreign investors as well as foreign loans/debts for the sake of infrastructure development. The era of the 1970s marked a revival of development in Jakarta, with steel and concrete construction buildings. The Indonesian Architects got a wider opportunity to experiment and practice their knowledge. The unfinished concrete buildings of Brutalism architecture began to appear in office and campus buildings.

But the question that emerged was, are all those big and massive building that were made of concrete categorized as Brutalism? The Brutalism's characteristic was not merely of concrete usage, but we can see the indications that built it up, that may open the understanding about Brutalism architecture in postcolonial Indonesia. The indications are : 
1) Vision of Modern Indonesia ; 2) The Development of Technology : Cement Industry ; 3) National Identity Through National Development Under the Reign of New Order (SocioPolitical Aspect) ; and 4) The Role of Architects.

\section{Research method}

This research applies a qualitative method using the historical method approach by reconstructing the past through collecting data supported by study of literature, study of archives, and also field observation is used to obtain data about the causes, impacts, or developments of past events, and then assess, verify, and populate the field evidence obtained.

\section{Brutalism architecture}

The history of the development of Brutalism occurred through events related to politics and the development of modernist architects' thinking in the 1950s. In Germany in 1950, Smithson, who echoed the concept of Brutalism, was one of the radical groups, as an ethical rebel against traditionalism with a conjecture of functionalism toward the aesthetics of modernism. But gradually in the development process, along with the role of Le Corbusier in his efforts to lift the brut béton - which speaks of a strong dialogue between material and his artistic vision [14] - the concept of Brutalism accepted into a charismatic concept. Such acceptance, according to von Buttiar, is essential for the development of Brutalism architecture in Germany, in the context of German-French reconciliation on cultural-political alternatives to be combined (annexed) by the dominant of the 'American Way of Life' [3]. In Netherlands, the Brutalism architecture was triggered off by the sculptor, Henry Moore, who rebuilt Bouwcentrum (1955). The building has been the first to be rebuilt from the ruins of the city due to attacks from Germany, Britain, and America during World War II. Moore was inspired by the Brutalism concept that emerged into the media in the early 1950s brought by Smithsons [10], in which Brutalism was a breakthrough for the overcoming of urban development that had been destroyed by war. This is what makes Brutalism entered and 'accepted' with ease by the Dutch.

Brutalism architectural characters brought by Smithson influenced by Jean Dubuffet (Art Brut of Dubuffet) - one of the contemporary artistic phenomena - to the art of brut / art of raw or, what I conclude, is a reflection of the honesty of the combined use of materials applied to the surface of a building, in general, it produces concrete buildings that have simple appearance and therefore generate 'hard' and blockish properties [9]. But now Brutalism has been transformed into a synonym that refers to buildings made of open concrete, regardless of when, where, and for what it was built [12].

As the theories and history of Brutalist's architecture emerged, it can be stressed that Brutalism architecture is a breakthrough as well as new architectural style that carries the concept of simple concrete structure (less ornament or not coated), hard and blockish. The architectural formation of Brutalism was also due to the urgency dominated postWorld War II so that war-affected countries in Europe needed a reconstruction to accommodate housing, schools and other facilities with cheap and efficient resources [4].

\section{Vision of modern indonesia}

After Indonesia has been regarded as a sovereign country, Soekarno made a major transformation in the field of architecture and urban planning as one of the Nation and 
Character Building. The spirit of modern Indonesia was triggered since his first state visit to India in 1950. At that time, Soekarno and Fatmawati went sightseeing in the city of New Delhi; to Red Ford, Qutb Minar, the Taj Mahal and these monuments had impressed upon them deeply. At that time, Soekarno compared the good city of New Delhi to the condition of Jakarta and its people who still occupied with the colonized mentality [13]. In mobilizing the Nation and Character Building, Soekarno was in charge of the movement itself and was assisted by the National Planner Council which established by Soekarno himself. The national projects started the movement after the 1959 Presidential Decree and the founding of the National Planning Development, often called the 'Mercu Suar' project which began in 1961. These projects include : National Art House, National Library, National Theater, National Museum, Museum of Struggle, etc. [13]. But the most highlighted are the developments that are not only included in the Mercu Suar project, but also the preparation for the 4th ASEAN Games in Jakarta, among them are Gelora Bung Karno stadium and the CONEFO building. During the leadership of Soekarno, Brutalist building is widely used for office buildings such as PPM Building and Aryaduta Hotel in Tugu Tani Street ; university building, such as UIRawamangun Campus ; and markets, such as Pasar Senen, Pasar Blok A, and Pasar Tanah Abang Lama ; monument, such as the Monument of Dirgantara Statue (Pancoran Statue) ; and buildings along MH Thamrin Street (see Fig. 1). The buildings are constructed with concrete and initially unpainted / plastered.

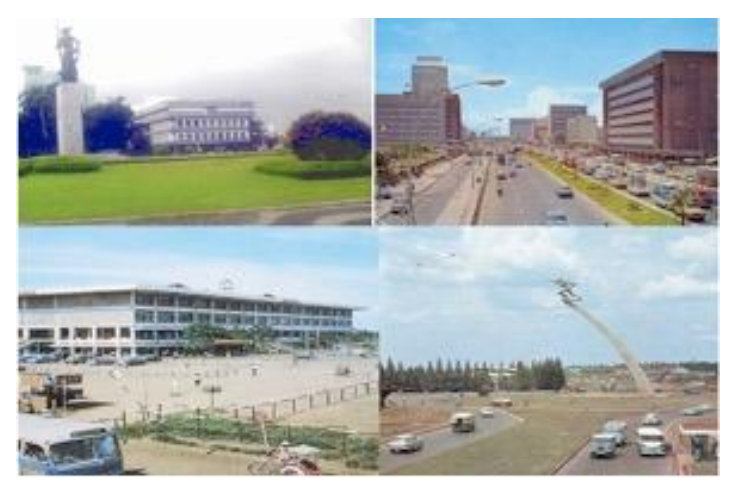

Fig. 1. Collage of Concrete Buildings in Jakarta in Old Order. Source kitlv, accessed March 5th, 2018.

As for the building of the Old Order era that was built from the concrete but originally already refined with a layer like marble is the Istiqlal Mosque (see Fig. 3), and also National Monument (see Fig. 2). So the element of Brutalism is not too prominent. 


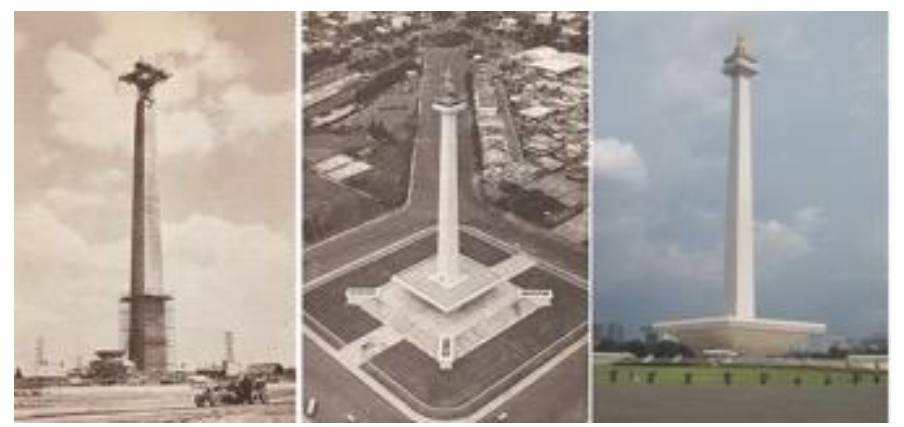

Fig. 2. Collage of the National Monument. Source https://www.twisata.com/objek-wisata-monumennasional-monas-icon-wisata-ibu-kota-jakarta/, accessed March 5th, 2018.

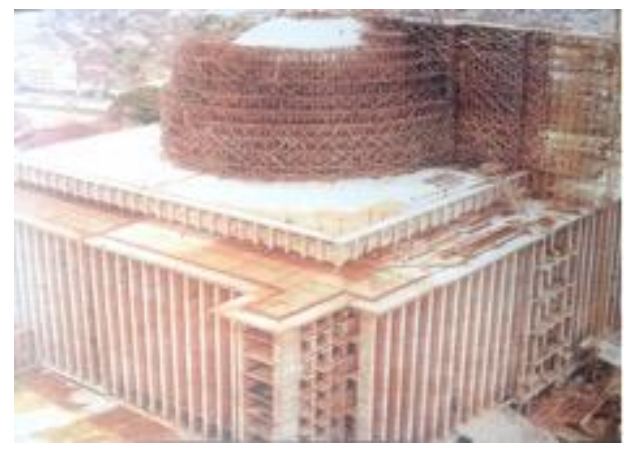

Fig. 3. The Construction Process of Istiqlal Mosque Dome. Source A. Armand et. Al., 2014

The above projects have the same structure that uses the main structure of concrete, although there is original concrete without coating and those already coated. These buildings are not the first buildings constructed with concrete in Indonesia, because when the reinforced concrete techniques were present at the beginning of the 20th century, there are already emerged infrastructure projects such as railway stations, schools, banks, and so on, partly structures made of concrete [1].

Soekarno's movement and vision provoked some question about why modern architecture was going to be 'the new face" of Indonesia development? I had once read about why modern architecture was used to raise Indonesia. According to Kusno, it is because modern architecture contains a set of meanings, missions, methods, and technology in answering the challenge of the times [2]. And why use concrete material? Soekarno's desire to use concrete as the structure in its development projects is based on the idea that concrete buildings are often referred to as 'Mansions' which are different from mere 'buildings' or 'houses', reflecting that concrete buildings are buildings with two or three levels, which is also explained that the concrete building is being disseminated as a marker of the modern era [1].

\section{The development of technology: Cement industry}

The establishment of NV Nederlandsch Indisch Portland Cement Maatschaapij (NV NIPCM) on March 18th 1910 as the first cement factory in Indonesia and Southeast Asia, 
precisely in Indarung, Padang, became a historic starting point where the development of European architectural styles, especially Brutalism, in Indonesia began. I realize the NIPCM era is way back than the postcolonial era, but the potential of cement as the main raw material for concrete material is an important role in the development of modern architecture in Indonesia. When entering the postcolonial era in 1940s, engineers were developing concrete technology. By 1955, Roosseno, an Indonesian structural and concrete expert sparked reinforced concrete technology. And in the decade of 1950s, cement factories set up by the indigenous people such as Semen Gresik in East Java (1957), Semen Tonasa in Makassar (1971), Semen Baturaja in Palembang (1974), Indocement in Cibinong (1975), Semen Kupang in Kupang (1980), Semen Andalas in Aceh (1984), etc. began to be established [1].

And what will happen after that? Since the engineers found that the new technology about concrete material and reinforced concrete being invented, the infrastructure development went rapidly, along the demand for development to support economic activities and globalization. This made the income of the state better due to the mutualism process gained from globalization and foreign investors, of which mostly happened in the New Order era.

\section{National identity through national development under the reign of new order (Socio-political aspect)}

The New Order reflected a significant difference. Soeharto wanted to create 'traditionality' as a state identity through development. Talking about the identity, the searching of National Identity is something that is simple but yet complicated. Nezzar AlSayyad liken it to looking for photographs or memories of the past. We know exactly what we were like, how we went through the years, but what is essential in our life is not explicitly written on the wall.

According to Soeharto's speech on the inauguration of Wisma Nusantara in 1972, he stated the very important thing, "...lets create a modern efficiency with own personal authenticity." In short, he wanted to create something new with the new interventions to bring Indonesia a National Identity. In his eyes, National Identity is so important. For hundred years Indonesia was under the colony so he wanted to make Indonesia free from the colony's shadows. The purpose is to giving intervention to the development's concept in order to reach the success of National Identit, starting with the Taman Mini Indonesia Indah (TMII) project that was initiated by Tien Soeharto, Soeharto's wife. TMII is Indonesia's miniature project from Sabang to Merauke which shows all sides of Indonesia, starting from the formation of typical buildings of each region, culture tribe, etc. From this moment, the new tendency was very clearly seen from this project. Because the TMII project provided political direction and also in view of the New Order, it was like as if recommending that government institution buildings and companies always represent cultural identity.

But the resulting problem in realizing this idea was the unbearable impact of capitalism and globalization so that Soeharto's efforts to form traditionality are offset by the swift build-up of skyscrapers to sustain business and economic activity. As stated by Prijotomo, "What is a matter of concern is the 'development' of architecture that is symbolically based on the image of 'traditios'. In this formulation, 'development' is far from eroding the sign of 'tradition"' [2], Soeharto's ideas are indeed acceptable and can be used as a reference for design strategy that will not be found in western architectural references, as well as a symbol and as a state identity. But in reality, the development is still far from reality and even 'disrupt' the image of the tradition. The swift flow of politics with the positive impact of increasing state revenues and the intake of foreign investors, provides 
an opportunity for architects who did not have more opportunities in the Old Order era to be able to explore devotees of International Style, one of which is Brutalism.

In the New Order era, architects who had not yet had a wide opportunity in the Old Order began to gain opportunities and chances in the New Order era as the impact of globalization with the emergence of foreign and private investors. So from here on out, the Brutalism architecture developed rapidly (see Fig. 4) (see Fig. 5).
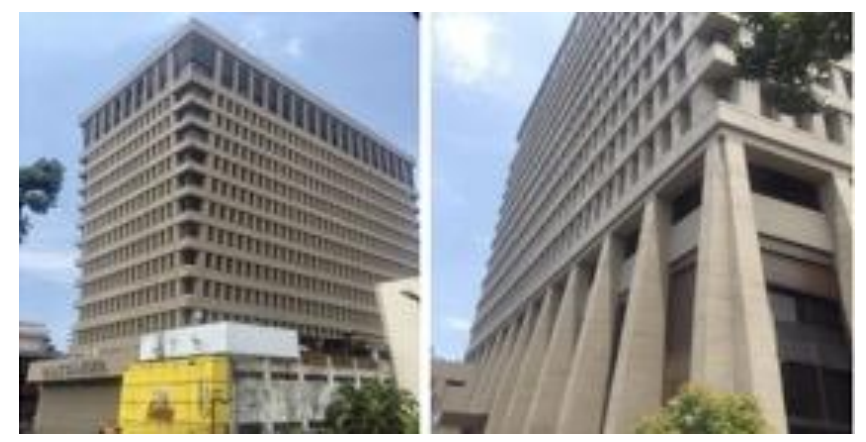

Fig. 4. Brutalisme at Wisma Hayam Wuruk. Source author, 2018.
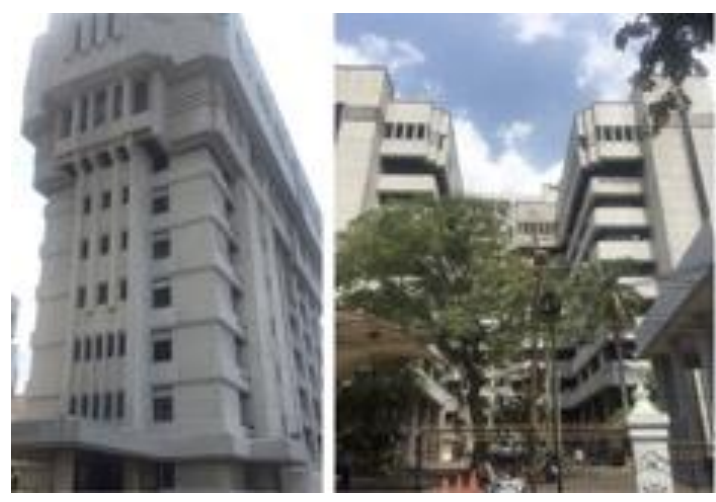

Fig. 5. Brutalism at Pierre Tendean Building \& Soeprapto Building at Indonesian Ministry of Defense Complex. Source author, 2018.

Some buildings at Wisma Hayam Wuruk and the Indonesian Ministry of Defense Complex can be categorized as a Brutalism architecture that were built during the New Order government. The use of uncoated concrete structures of any coating material gives rise to a sturdy and innocent impression when we first see it.

\section{The role of architects}

The rapid development of the economy can not be separated from the New Order government policy that plays mutualism politics, by allowing capitalism as a national development tool that opens the widest gates for private and foreign investors. And then with the skyscrapers established, commercial activity spaces, and financial centers express a modern and accommodating lifestyle. Implementation of modern international styles such as Brutalism can be expressed during the New Order regime, when in return, the state's 
economy was supported by the revenue derived from state enterprises and investors. I conclude, the purpose of making a national identity by raising everything related to traditionality somewhat hampered due to the rapid flow globalization.

And in a good way, this condition enables the young architects more freedom with different expression and enthusiasm than in the Old Order. The architects are Soejoedi, the senior Frederich Silaban, Y.B. Mangunwijaya, Yuswaldi Saliya, and Han Awal, to name a few. They were the ones who returned to their homeland after studying in the Netherlands. Along with the presence of teachers from Europe and America during the crisis of nationalization of foreign companies in Indonesia in the 1960s decades, these young architects returned with ideas and open thoughts about dynamic global architecture discourse - that is international style - which is the style of the building as well as a new movement in the discourse of modern architecture post-World War II, which began to use a lot of concrete technology in its construction. Under these circumstances, the acceptance of Indonesian architects to embrace and adapt to the developments of international architecture to be applied to modern buildings in Indonesia began.

For example, in continuing Old Order's project in New Order era, Soejoedi was designing buildings more expressively with symmetrical and plastic shapes. He relied heavily on the flexibility of reinforced concrete material like the CONEFO building. Different from Soejoedi, Silaban is an architect who gives a rigid image to the concrete buildings he made. Such Masjid Istiqlal, which its objectivity was very concerned. Application of wall coverings is carried out considering the problem of moisture, capillarity of water, and salt content are things that often occur in tropical buildings. The solution applied to protect the plaster from the construction of the wall by applying marble for its finishing, so that is not vulnerable to damage.

The principle that does not give a raw impression on concrete may conflict with the style of Brutalism that is attached to plain concrete. But in the other hand, it will be a new derivative thing in the modern Brutalism style in postcolonial Indonesia.

The New Order reflects differences from the Old Order. The Old Order wants to change the face of Indonesia in the eyes of the world from the colonial state to a sovereign modern state by realizing a modern way, while the New Order actually utilized the development to bring traditionality as a national identity. And vice versa, something done for the same purpose.

\section{Conclusion}

Brutalism architecture entered Indonesia along with the development of several sociopolitical conditions, led by President Soekarno who want to realize the vision of a modern Indonesia through architectural discourse. After President Soeharto's regime, the project continued with a 'new tendency'. Architectural development in both eras was influenced by political and technological conditions - since reinforced concrete invented and developed. The stability of economic conditions trigger young architects to express their work with new thought and ideas derived from international, modern, and cutting-edge technology.

This research and its publication has been funded by Universitas Indonesia under PITTA (Publikasi Internasional Terindeks untuk Tugas Akhir Mahasiswa UI) program year 2018, contract number : 2467/UN2.R3.1/HKP/05.00/2018.

\section{References}

1. A. Armand et al., Ketukangan: Kesadaran Material, Jakarta: IMAJI, 2014. 
2. A. Kusno, Behind the Postcolonial: Architecture, Urban Space and Political Cultures in Indonesia, New York: Routledge, 2000.

3. A. von Buttiar, Brutalism in Germany: The Pathos of Progress as Aesthetic Revolt, in SOS Brutalism, pp. 66, Park Books, 2017.

4. B. Calder, British Brutalisms New and Newer, in SOS Brutalism, pp. 27, Park Books, 2017.

5. B. Tschumi, The Please of Architecture, in Kate Nesbitt (ed) Theorizing a New Agenda for Architecture. An Anthology of Architectural Theory, pp.534, New York : Princenton Architectural Press, 1966.

6. B. Sukada, Membuka Selubung Cakrawala Arsitek Soejoedi, Jakarta: Gubahlaras Arsitek \& Perencana, 2011.

7. G. Tjahjono, Arsitektur di Indonesia: Kancah Penjelajahan Tanpa Batas, in his Proessor's Inaugural Speech Architecture Department, Universitas Indonesia, pp. 3, Depok December $28^{\text {th }} 2002$.

8. J. Derrida, as interviewed by Eva Meyer Architecture Where the Desire May Live, in Neil Leach (ed) Rethinking Architecture. A Reader in Cultural Theory, pp. 319, London and New York : Routledge, 1997.

9. K. Frampton, A Critical History Modern Architecture, London: Thames and Hudson, 1980.

10. L. Lefaivre, Aldo van Eyck, the Humanist Rebellion, and the Reception of Brutalism in the Netherlands, in SOS Brutalism, pp. 77, Park Books, 2017.

11. M. Hays, Architecture's Desire: Reading the Late Avant-Garde, pp.1-20, Cambridge : MIT Press, 2010.

12. O. Elser, Just What Is It That Makes Brutalism Today Appealing? A New Definition From an International Perspective, in SOS Brutalism, pp. 15, Park Books, 2017.

13. Pusat Data Arsitektur, Tegang Bentang, Jakarta: PT. Gramedia Pustaka Utama, 2012.

14. R. Gargiani and A. Rosellini., Le Corbusier: Béton Brut and Ineffable Space, 1940 - 1965. Surface Materials and Psychophysiology of Vision. EPFL Press, 2011.

15. Y. Ardhiati, Panggung Indonesia : Khora Pesona Karya Arsitek Soekarno 1960an, Disertation UI: 2012. 